\title{
PENGARUH KEPUASAN KERJA, MOTIVASI DAN GAYA KEPEMIMPINAN TERHADAP KINERJA PEGAWAI PADA SEKOLAH TINGGI AGAMA ISLAM NEGERI BATUSANGKAR
}

\section{Hemayulis Syam}

STAIN Batusangkar, Koresponden: J In. J enderal Sudiman Nomor 137 Lima Kaum Batusa sngkar, e-mail: hemayuliswilmarara@gmail.com

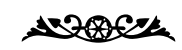

\begin{abstract}
Abstrak; Effect of Job Satisfaction, Motivation and Leadership Styles Of Employee Performance in Sekolah Tinggi Agama Islam Negeri Batusanggkar. Issues raised in this study is whether job satisfaction, motivation and leadership styles affect the performance of employees at STAIN Batusangkar. This study aims to determine the effect of job satisfaction, motivation and leadership style on employee performance at Sekolah Tinggi Agama Islam Negeri Batusanggkar (STAIN) Batusanggkar.

The results of hypothesis testing showed that: (1) there is a positive and significant impact employee job satisfaction on employee performance STAIN Batusanggkar the effective contribution of $6.3 \%$ and 0.047 significance. (2) there is a positive and significant impact employee motivation STAIN Batusanggkar the effective contribution of $21.23 \%$ and a significance of 0.000 . (3) there is a positive and significant effect of leadership style on employee performance by employees Batusanggkar effectively $6.5 \%$ and significance of 0.044 . (4) there is a positive and significant effect of job satisfaction, work motivation and leadership styles as perceived by employees STAIN Batusanggkar the effective contribution of $50.4 \%$ and a significant 0.000 .
\end{abstract}

Kata Kunci: Kepuasan kerja, motivasi, gaya kepemimpinan, kinerja

\section{PENDAHULUAN}

Peningkatan kinerja secara tepat hanya dapat dilakukan berdasarkan hasil evaluasi terhadap kinerja saat ini, karena hasil evaluasi kinerja menunjukkan tingkat pengelolaan seseorang dalam melaksanakan tugas yang menjadi tanggung jawabnya. Kinerja yang rendah menunjukkan kurangnya kemampuan pengelolaan tugas atau organisasi yang menjadi tanggung jawab masing-masing pegawai, sehingga berakibat pada terhambatnya pencapaian tujuan organisasi. Sebaliknya kinerja yang tinggi mencerminkan kemampuan pengelolaan tugas yang tinggi yang pada akhirnya akan berdampak pada kinerja organisasi yang lebih baik.

Berdasarkan uraian di atas, terlihat betapa pentingnya peranan pimpinan dalam meningkatkan kepuasan kerja, motivasi kerja 
dalam meningkatkan kinerja pegawai, gaya kepemimpinan yang tepat akan mampu memberikan dorongan dan mengarahkan pegawai dalam bekerja dan akan membuat pegawai menjadi disiplin serta termotivasi dalam bekerja.

Kepemimpinan sebagai proses menggerakkan orang lain, pada dasarnya merupakan rangkaian interaksi antar manusia. Interaksi itu bersumber dari seseorang yang berani dan bersedia tampil mempelopori dan mengajak orang lain berbuat sesuatu melalui kerja sama satu dengan yang lainnya. Dengan berada di depan seorang pemimpin akan menjadi ikutan, yang sikap dan perilakunya ditauladani. Bersamaan dengan itu pemimpin juga selalu mampu berada di tengah orang yang dipimpinnya untuk bergandengan tangan atau bekerja sama dalam mewujudkan kegiatan bersama. Untuk itu pemimpin berfungsi sebagai teman yang saling bantu membantu dalam mewujudkan kegiatan yang memerlukan kerja sama.

Pemimpin memegang peranan yang sangat penting untuk menggerakan bawahannya dalam rangka mencapai tujuan organisasi. Pemimpin pada sebuah harus mampu mempengaruhi bawahan agar dapat melaksanakan tugasnya dengan baik, pemimpin juga harus bisa dekat dengan bawahannya, agar bawahannya merasa tenang menerima bimbingan dan arahan oleh atasannya, hal ini sesuai dengan firman Allah dalam surat Shad ayat 26 yang berbunyi :

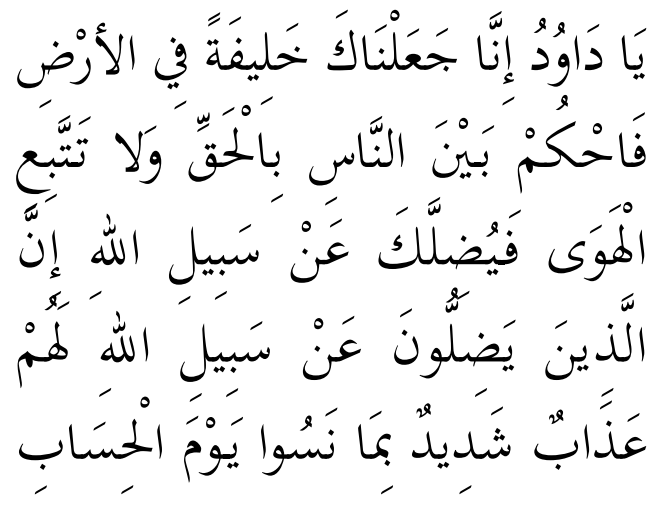

"Hai Daud, sesunggubnya Kami menjadikan kamu khalifah (penguasa) di muka bumi, maka berilah keputusan (perkara) di antara manusia dengan adil dan janganlah kamu mengikuti hawa nafsu, karena ia akan menyesatkan kamu dari jalan Allah SWT. Sesungguhnya orang-orang yang sesat dari jalan Allah SWT akan mendapat azab yang berat, karena mereka melupakan hari perhitungan." (Qs Shad: 26)

Oleh karena itu salah satu peran dari pemimpin adalah menerapkan gaya kepemimpinan yang efektif agar tujuan organisasi dapat dicapai sesuai dengan rencana.Allah memerintahkan pada semua pemimpin agar dalam memimpin berusaha mempergunakan akal/pikirannya, terutama dalam menganalisa dan memanfaatkan situasi/kondisi yang dihadapinya, usaha tersebut akan berpengaruh terhadap perkembangan organisasi yang dipimpinnya, kalau kita perhatikan firman Allah dalam Surat Yunus ayat 101 yang berbunyi:

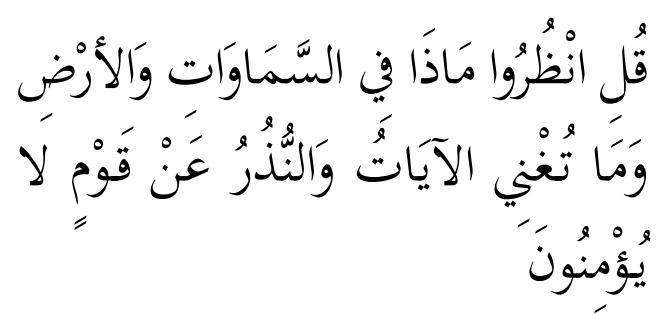


"Katakanlah: "Perhatikanlah apa yangada di langit dan di bumi, tidaklah bermamfaat tanda kekuasaan Allah dan Rasul-rasulyang memberi peringatan bagi orang-orang yang tidak beriman" (Yunus ayat 101).

Dari ayat di atas dijelaskan bahwa tandatanda kekuasaan Allah SWT bagi seorang pemimpin yang beriman terdapat juga dalam interaksi sesama manusia. Seorang pemimpin dalam Islam diharapkan bisa bekerja dan memimpin berlandaskan pada ajaran Islam dan berpedoman pada Al-Quran dan Hadis.

Kinerja pegawai dapat dilihat dari berbagai faktor, baik itu faktor internal yaitu: minat kerja, motivasi, kecerdasan, pengetahuan dan wawasan pegawai, maupun faktor eksternal (disiplin, upah, insentif, dan lingkungan kerja). Kinerja pegawai dengan sendirinya akan mengalami peningkatan apabila semua komponen yang terkait dengan instansi tempat bekerja diperbaiki, baik itu faktor internal dan eksternal. Apabila seluruh komponen ini berjalan dengan baik maka tujuan organisasi dan instansi akan mudah dicapai.

Di STAIN Batusangkar pegawai merupakan salah satu komponen yang menunjang kegiatan administrasi, perpustakaan, laboratorium, keuangan bahkan proses belajar mengajar. Keberhasilan STAIN Batusangkar juga ditentukan oleh kinerja pegawainya. Seorang pegawai yang mempunyai kinerja tinggi seharusnya mempunyai sikap positif terhadap pekerjaan yang menjadi tanggung jawabnya, sikap tersebut misalnya disiplin, suka bekerja dengan sungguh-sungguh, menjaga kualitas kerjanya, bertanggung jawab, berdedikasi tinggi dan sebagainya.

Kenyataan menunjukan masih ada pegawai yang datang terlambat, pekerjaan yang menumpuk di akhir tahun, terburuburu menyelesaikan pekerjaan apabila akan ada pemeriksaan, terburu-buru melengkapi bahan di kala mau diperiksa, lokal, ruangan,papan tulis yang kotor karena tidak dibersihkan secara rutin.

Berdasarkan hasil wawancara Penulis dengan Kasubbag Kepegawaian dan Keuangan STAIN Batusangkar, bahwanya pada STAIN Batusangkar kinerja pegawai sudah mulai menurun, kebiasaan pegawai yang datang tidak tepat waktu dan lalai dalam tugas sudah mulai menjamur. Banyak dari para pegawai yang bekerja di STAIN Batusangkar mulai lupa dengan tanggung jawab mereka sebagai mengemban amanah masyarakat. Sangat disayangkan jika kondisi ini terus berlanjut, karena tugas dan tanggung jawab yang diembankan kepada para pegawai ini tidaklah mudah, hal ini berkaitan dengan kemajuan pendidikan masa yang akan datang khususnya bagi daerah Batusangkar.

Berdasarkan kondisi tersebut penulis sangat tertarik untuk melakukan penelitian mengenai kinerja pegawai STAIN Batusangkar terkait dengan kepuasan Kerja, motivasi dan gaya kepemimpinan di STAIN Batusangkar. 
Permasalahan dalam penelitian ini dapat dirumuskan yaitu apakah kepuasan kerja, motivasi dan gaya kepemimpinan berpengaruh terhadap kinerja pegawai pada STAIN Batusangkar.

Tujuan yang ingin dicapai dalam penelitian ini untuk mengetahui pengaruh kepuasan kerja, motivasi dan gaya kepemimpinan terhadap kinerja pegawai pada Sekolah Tinggi Agama Islam Negeri (STAIN) Batusangkar.

\section{PEMBAHASAN}

\section{Kinerja Pegawai}

Pengertian kinerja menurut Kamus Besar Bahasa Indonesia adalah (1) sesuatu yang dicapai, (2) prestasi yang diperlihatkan, dan (3) kemampuan kerja (Departemen Pendidikan Nasional, 1991:397). Kata kinerja merupakan terjemahan dari kata performance (bahasa Inggris), dan kata ini biasa juga disebut dengan prestasi kerja atau penyelenggaraan kerja (Adi K Gunawan, 2002:279).

Kinerja atau prestasi kerja diartikan sebagai ungkapan kemampuan yang didasari oleh pengetahuan, sikap, keterampilan dan motivasi dalam menghasilkan sesuatu.

Proses kerja selalu mempunyai langkahlangkah kerja yang senantiasa mengarah pada pencapaian hasil pekerjaan yang sesuai dengan tuntutan kerja. Apabila suatu pekerjaan dilaksanakan sesuai dengan prosedurnya, maka akan sampai kepada hasil kerja yang diinginkan, yang merupakan tuntutan pekerjaan tersebut. Tolok ukur dari kinerja adalah tuntutan pekerjaan yang mengambarkan hasil yang ingin dicapai.

Menurut Veithzal Rivai dikatakan kinerja sebagai suatu fungsi dari motivasi dan kemampuan. Untuk menyelesaikan tugas dan pekerjaan, seseorang harus memiliki derajat kesediaan dan tingkat kemampuan tertentu (Veithzal Rivai, 2005:14). Wahjosumidjo berpendapat bahwa kinerja adalah "hasil kerja yang disumbangkan oleh seseorang atau kelompok dalam menunjang tercapainya tujuan sekolah" (Wahdjosumidjo, 2001:430).

Menurut Komarudin beberapa faktor yang diduga mempengaruhi kinerja seseorang antara lain adalah besar kecilnya pendapatan serta jaminan sosial, tingkat pendidikan dan latihan, sikap, motivasi, disiplin, etika kerja, kesehatan, hubungan sosial, manajemen, sarana produksi, kesempatan berprestasi, kepuasan, teknologi dan kebijakan pemerintah (Komaruddin, 1992:112).

Menurut Hasibuan, kerja adalah pengorbanan jasa, jasmani dan fikiran untuk menghasilkan barang-barang atau jasajasa dengan memperoleh imbalan prestasi tertentu (Malayu Hasibuan, SP, 2005:94). Sebagaimana Allah berfirman dalam AlQur'an:

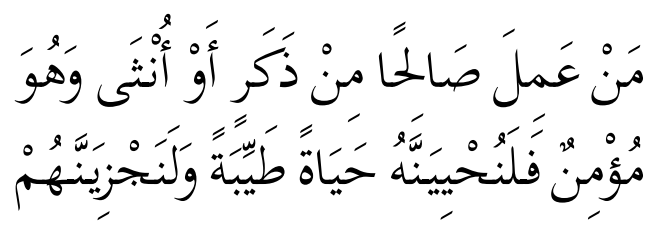






"Barang siapa yang mengerjakan amal saleh, baik laki - laki maupun perempuan dalam keadaan beriman, maka sesungguhnya kami berikan kepadanya kehidupan yang baik, dan sesungguhnya akan kami beri balasan kepada mereka dengan pahala yang lebih baik dari pada yang telah mereka kerjakan". (QS. 16:97)

Maksud dari ayat diatas adalah Allah menyuruh manusia agar mempunyai kinerja yang baik yakni suatu pekerjaan yang dilakukan dengan sadar dan ikhlas sesuai dengan normanorma dan aturan yang terdapat dalam agama Islam, sehingga apa yang dilakukan akan mendapat balasan dari Allah SWT.

Berdasarkan beberapa pandangan para ahli di atas, dapat disimpulkan bahwa kinerja pegawai adalah hasil kerja yang dapat dicapai oleh seseorang atau sekelompok orang dalam suatu organisasi sesuai dengan wewenang dan tanggung jawab masing-masing, dalam rangka mencapai tujuan organisasi bersangkutan secara legal, tidak melanggar hukum dan sesuai dengan moral maupun etika.

\section{Faktor-faktor yang mempengaruhi kinerja pegawai}

\section{a. Kepuasan kerja}

Kepuasan kerja merupakan bentuk perasaan seseorang terhadap pekerjaannya, situasi kerja dan hubungan dengan rekan kerja. Dengan demikian kepuasan kerja merupakan sesuatu yang penting untuk dimiliki oleh seorang karyawan, dimana mereka dapat berinteraksi dengan lingkungan kerjanya sehingga pekerjaan dapat dilaksanakan dengan baik dan sesuai dengan tujuan suatu lembaga

\section{b. Motivasi kerja}

Motivasi merupakan hasil sejumlah proses yang bersifat internal atau eksternal bagi seorang individu, yang menyebabkan timbulnya sikap entusiasme dan persistensi dalam hal melaksanakan kegiatan-kegiatan tertentu. Menurut Stephen P. Robbins motivasi adalah kesedian untuk mengeluarkan tingkat upaya yang tinggi untuk tujuan organisasi, yang dikondisikan oleh kemampuan seseorang dalam memenuhi beberapa kebutuhan individual (Stephem P Robbins, 2003:208).

Berikut adalah Surat At-Taubah ayat 105 yang berkisar pada kata-kata yang memberikan motivasi kerja, yaitu

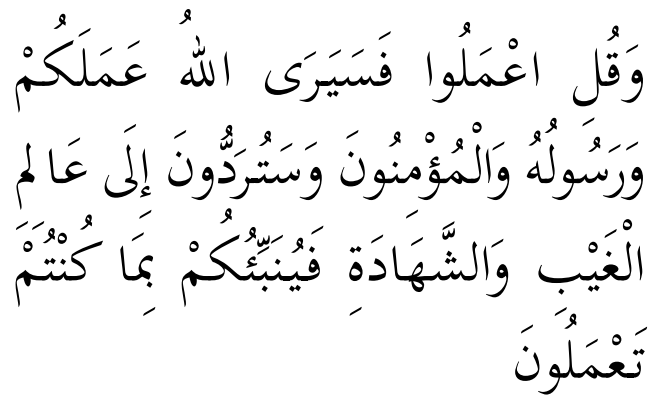

"Dan Katakanlah: "Bekerjalah kamu, Maka Allah dan Rasul-Nya serta orangorang mukmin akan melihat pekerjaanmu itu, dan kamu akan dikembalikan kepada (Allah) yang mengetahui akan yang ghaib dan yang nyata, lalu diberitakan- 
Nya kepada kamu apa yang telah kamu kerjakan". (QS At-Taubah ayat 105).

\section{c. Gaya kepemimpinan}

Menurut teori kepemimpinan situasional dari Hersey dan Blanchard, ada empat gaya kepemimpinan yaitu:

1) Gaya kepemimpinan direktif

Setiap pemimpin perlu memiliki kemampuan dalam memberikan perintah yang bersifat komuniukatif (Hadari Nawawi, Kepemimpinan Menurut Islam, (Yokyakarta, 2011:143). Tipe atau gaya kepemimpinan ini ditandai dengan adanya komunikasi satu arah. Pimpinan membatasi peranan bawahan apa, kapan, dimana, dan bagaimana sesuatu tugas dilaksanakan. Pemecahan masalah dan pengambilan keputusan semata-mata menjadi tanggung jawab pemimpin.

2) Gaya kepemimpinan konsultatif Pemimpin tipe konsultatif masih memberikan arahan yang cukup besar kepada bawahannya baik dalam proses pembuatan keputusan maupun dalam pelaksanaannya. Bedanya dengan tipe direktif, dalam tipe ini pemimpin menggunakan komunikasi dua arah dan memberikan suportif terhadap bawahan. Pemimpin mau mendengarkan keluhan dan perasaan bawahan mengenai keputusan yang diambil. Pada gaya kepemimpinan ini, pemimpin berusaha meningkatkan bantuannya kepada bawahannya, tetapi tanggung jawab pelaksanaan keputusan tetap pada pimpinan.

3) Gaya kepemimpinan partisipatif Pada gaya kepemimpinan ini, control atas pemecahan masalah dan pengambil keputusan antara pemimpin dan bawahan bersifat seimbang. Pemimpin dan bawahan sama-sama terlibat dalam proses pengambilan keputusan. Komunikasi dua arah semakin meningkat. Pemimpin semakin mendengarkan secara intensif terhadap pendapat bawahannya.Dalam tipe ini pemimpin berpendapat bahwa bawahannya memiliki kecakapan dan pengetahuan yang luas untuk menyelesaikan tugas sesuai dengan fungsinya dan perannya masing-masing dalam suatu organisasi.

4) Gaya kepemimpinan delgatif Pada gaya kepemimpinan delegatif, pemimpin berusaha mendiskusikan masalah-masalah yang dihadapi dengan bawahannya, dan selanjutnya mendelegasikan pengambilan keputusan seluruhnya kepada bawahan.

Penelitian ini tergolong penelitian korelasional yang bertujuan untuk mengukur tentang ada atau tidak adanya Pengaruh antara dua atau lebih dari variabel yang diajukan peneliti dengan ukuran-ukuran yang valid dan reliabel (Abdul Halim hanafi, 2010:124). 
Dalam penelitian ini penulis memakai metode kuantitatif yang bersifat penelitian korelasional, sementara analisis yang digunakan adalah analisis regresi ganda, ini merupakan suatu metode untuk mengetahui kontribusi kolektif dari dua atau lebih variabel bebas $(\mathrm{X})$ terhadap variabel terikat (Y). Dengan memakai metode ini nanti akan kelihatan ada atau tidak adanya pengaruh kepuasan kerja, motivasi kerja dan gaya kepemimpinan kerhadap kinerja pegawai di STAIN Batusangkar.

Hasil penelitian ini menunjukan bahwa dari 65 orang karyawan STAIN Batusangkar yang menjadi responden $21,54 \%$ memiliki kinerja sangat tinggi, 27,69\% memiliki kinerja tinggi, 41,54 memiliki kinerja sedang, 9,23\% memiliki kinerja rendah dan tidak ada karyawan STAIN Batusangkar yang memiliki kinerja sangat rendah. Kinerja ini ditunjukan karyawan STAIN Batusangkar dalam melaksanakan tugas sehari-hari yang menjadi tanggung jawabnya.

Kualitas kinerja karyawan berpengaruh terhadap terwujudkan keberhasilan seluruh kegiatan di STAIN Batusangkar. Seorang karyawan yang memiliki kinerja yang tinggi diharapkan lebih produktif dan keberhasilan kerja yang tinggi. Sebaliknya karyawan yang memiliki kinerja yang rendah dapat menyebabkan kurang produktif dan keberhasilan juga rendah. Oleh karena itu perlu diperhatikan faktor-faktor yang dapat mempengaruhi kinerja seorang karyawan. Output analisis regresi menunjukkan nilai korelasi anda sebesar 0,710 , nilai koefisien determinan sebesar 0,504 , nilai $\mathrm{F}_{\text {hitung }}$ sebesar 20,679 dengan signifikansi 0,000 kurang dari 0,05. Berdasarkan pengujian ini dapat disimpulkan bahwa:

1. Secara simultan kepuasan kerja, motivasi dan gaya kepemimpinan menurut persepsi karyawan mempengaruhi kinerja karyawan STAIN Batusangkar sebesar 50,4\%, sedangkan 49,6\% disebabkan oleh faktor lain yang tidak termasuk variabel penelitian ini.

2. Terdapat pengaruh positif dan signifikan dari kepuasan kerja, motivasi, dan gaya kepemimpinan menurut persepsi karyawan terhadap kinerja karyawan STAIN Batusangkar. Pengaruh variabel bebas terhadap terikat tersebut positif artinya jika kepuasan kerja, motivasi, dan gaya kepemimpinan menurut persepsi karyawan secara bersamasama ditingkatkan maka kinerja karyawan STAIN Batusangkar juga akan meningkat.

Secara deskriptif penelitian ini berhasil mengungkap dari 65 karyawan yang menjadi responden $1,54 \%$ karyawan memiliki kepuasan kerja sangat tinggi, 26, 15\% memiliki kepuasan kerja tinggi, 44,62\% memiliki kepuasan kerja sedang, 24,62\% memiliki kepuasan kerja rendah, dan 3,08 memiliki kepuasan kerja sangat rendah.

Hasil pengujian hipotesis menunjukan terdapat pengaruh positif dan signifikan dari kepuasan kerja karyawan terhadap 
kinerja karyawan STAIN Batusangkar. Nilai korelasi parsialnya antara kepuasan kerja dengan kinerja sebesar 0,251,sedangkan pengaruh positif artinya jika kepuasan kerja karyawan di tingkatkan maka kinerja karyawan STAIN Batusangkar meningkat. Nilai koefisien determinasinya diperoleh dengan mengkuadratkan nilai korelasinya. Diperoleh nilai koefisien determinasi sebesar 0,063 artinya kepuasan kerja karyawan mempengaruhi kinerja karyawan STAIN Batusangkar sebesar $6,3 \%$, sedangkan 93,7\% dipengaruhi oleh variabel lain baik yang termasuk dalam penelitian ini maupun yang tidak termasuk dalam penelitian ini.

Temuan lain dalam penelitian berhasil mengungkapkan dari 65 karyawan yang menjadi responden 32,31\% karyawan STAIN Batusangkar memiliki motivasi kerja sangat tinggi, 40,00\% memiliki motivasi kerja tinggi, 23,08\% memiliki motivasi kerja sedang, 4,62\% memiliki motivasi kerja rendah, dan tidak ada karyawan STAIN Batusangkar yang memiliki motivasi kerja sangat rendah. Motivasi kerja karyawan meningkat karena karyawan ingin lebih sejahtera, berprestasi, berkembang, menyenangi pekerjaan, rasa tanggung jawab, ingin naik pangkat, ingin DP3 baik, ingin diperhatikan atasan, ingin diperhatikan sesama karyawan, dan ingin disegani oleh mahasiswa.

Hasil pengujian hipotesis menunjukkan bahwa terdapat pengaruh positif dan signifikan antara motivasi kerja karyawan terhadap kinerja karyawan STAIN Batusangkar. Korelasi parsialnya antara motivasi kerja dengan kinerja adalah sebesar 0,462 , sedangkan pengaruh positif artinya jika motivasi kerja karyawan ditingkatkan maka kinerja karyawan STAIN Batusangkar meningkat. Nilai koefisien determinasinya diperoleh dengan mengkuadratkan nilai korelasi parsialnya. Diperoleh koefesien determinasi sebesar 0,213 artinya motivasi kerja karyawan STAIN Batusangar mempengaruhi kinerja karyawan STAIN Batusangkar sebesar 21,3\% sedangkan 78,7 dipengaruhi oleh variabel lain, baik yang termasuk dalam penelitian ini maupun variabel yang tidak tidak termasuk dalam penelitian ini.

Penelitian ini juga berhasil mengunkapkan dari 65 karyawan yang menjadi responden $10,77 \%$ merasakan gaya kepemimpinan sangat baik, 24,62\% merasakan gaya kepemimpinan baik, $33,85 \%$ merasakan gaya kepemimpinan cukup, 20\% merasakan gaya kepemimpinan kurang, 10,77\% merasakan sangat kurang. Gaya kepemimpinan terdiri dari direktif, konsultatif, partisipatif, dan kepemimpinan delegatif.

\section{PENUTUP}

Berdasarkan hasil penelitian dan analisis adalah dapat disimpulkan bahwa: (1) terdapat pengaruh positif dan signifikan kepuasan kerja karyawan terhadap kinerja karyawan STAIN Batusangkar dengan sumbangan efektifnya sebesar $6,3 \%$ serta signifikansi 0,047. (2) 
terdapat pengaruh positif dan signifikan motivasi kerja karyawan STAIN Batusangkar dengan sumbangan efektifnya $21,23 \%$ serta signifikansi 0,000. (3) terdapat pengaruh positif dan signifikan gaya kepemimpinan menurut karyawan terhadap kinerja karyawan Batusangkar dengan efektif $6,5 \%$ serta signifikansi 0,044. (4) terdapat pengaruh positif dan signifikan kepuasan kerja, motivasi kerja dan gaya kepemimpinan menurut persepsi karyawan STAIN Batusangkar dengan sumbangan efektifnya sebesar 50,4\% serta signifikan 0,000.

Berdasarkan kesimpulan yang diperoleh penulis menyarankan sebagai berikut:

1. Para karyawan hendaknya diberi penghargaan atas prestasi kerjanya supaya karyawan dapat bekerja dengan motivasi kerja yang tinggi.

2. Pimpinan harus selalu meningkatkan kemampuan membaca situasi, supaya dapat menerapkan gaya kepemimpinan yang sesuai dengan kebutuhandan situasi.

\section{KEPUSTAKAAN ACUAN}

Abdul Halim Hanafi, 2010, Metodologi Penelitian Kependidikan, Batusangkar: STAIN Press.
Adi K Gunawan. 2002, Kamus Lengkap Indonesia-Ingris, Ingris-Indonesia. Surabaya : Kartika.

Asifudin, Ahmad Janan, 2004, Etos Kerja Islami, Surakarta: Muhammadiyah University Press

Depertemen Agama RI, Al-qur'an Al karim dan terjemahannya, Semarang: PT. Karya Toha Putra

Hadari Nawawi, 2011, Kepemimpinan Menurut Islam, (Yokyakarta: Gadjah mada University Press

Komaruddin, 1992, Manajemen pengawasan kualitas terpadu. Jakarta; Rajawali Press

Malayu Hasibuan, 2005SP, Manajemen Sumber daya Manusia, Jakarta: Bumi Aksara

Stephem P Robbins, 2003, Perilaku Organisasi, Jakarta: Indeks Kelompok Gramedia,

Veithzal Rivai, 2005, Manajemen Sumber Daya Manusia,Jakarta : Raja Gravindo Persada

Wahdjosumidjo, 2001 , Perilaku Kepemimpinan dan Motivasi, Jakarta: Cholia Indonesia 